\title{
Transatlantica
}

Revue d'études américaines. American Studies Journal

\section{A Few Remarks on the Poetics of Turbulence in Richard Powers' Operation Wandering Soul}

Jean-Yves Pellegrin

\section{(2) OpenEdition}

\section{Journals}

Édition électronique

URL : https://journals.openedition.org/transatlantica/4532

DOI : $10.4000 /$ transatlantica.4532

ISSN : 1765-2766

Éditeur

Association française d'Etudes Américaines (AFEA)

Référence électronique

Jean-Yves Pellegrin, "A Few Remarks on the Poetics of Turbulence in Richard Powers' Operation Wandering Soul », Transatlantica [En ligne], 2 | 2009, mis en ligne le 07 février 2010, consulté le 31 janvier 2023. URL : http://journals.openedition.org/transatlantica/4532 ; DOI : https://doi.org/ 10.4000/transatlantica.4532

Ce document a été généré automatiquement le 31 janvier 2023.

Creative Commons - Attribution - Pas d'Utilisation Commerciale - Pas de Modification 4.0 International - CC BY-NC-ND 4.0

https://creativecommons.org/licenses/by-nc-nd/4.0/ 


\title{
A Few Remarks on the Poetics of Turbulence in Richard Powers' Operation Wandering Soul
}

\author{
Jean-Yves Pellegrin
}

Operation Wandering Soul is, to a large extent, a novel about movement. It opens with a depiction of traffic flow on a Californian freeway, and from variation to variation this inaugural motif weaves its way through the whole book, filling it with floods of travelers, pilgrims, migrants, and all manner of displaced persons. Right from the beginning however this movement turns out to be problematic. Its progress, direction and place of destination are unclear. Freeways are no straight lines-"Freeways, like rivers, age and meander" (5), the narrator says-and traffic is sensitive to a whole range of interferences that disturb its ideally smooth and regular flow as the novel's main protagonist notices: “A lazy, Quaalude cross-drift of traffic skims across Kraft's viewing screen, flow and counterflow canceling out in diffraction pattern to form a standing wave" (5). The metaphors and alliterations in the beginning of the sentence combine here to conjure up the vision of a viscous, apathetic, sedated flow whose motion, direction and final destination threaten to vanish into pure wishful thinking.

2 As the reader is soon to realize, this problem reverberates throughout the book whose many embedded narratives struggle to steer their courses in the most straightforward manner to some ever postponed or missing conclusion; their traveling characters never seem to reach their goals, they wander, scatter, or vanish, and the stories end in ambiguity, if at all. Offering us two different endings, the novel itself is no exception to the rule. Unlike the inset pieces it contains, however, Powers' text as a whole does not even try to conform to the failing model of the straight narrative line. On the contrary the novel conspicuously departs from it, emphasizing its own discontinuity, and replacing linearity with circularity. The main narrative strand, which documents a few weeks in the life of Richard Kraft, a resident surgeon at Carver General in Angel City, is periodically-though unexpectedly-interrupted by passages from textbooks, history books, encyclopedias, and collections of tales which bear no immediate connection to 
the main narrative and break it up randomly into a series of discrete units. Besides, as both the principal and embedded narratives return obsessively to the same motifs of runaway children and abducting adults, the text adopts a distinctly cyclical turn. The general structure of the book thus superimposes on its fragmented linearity a spiral and unpredictable movement which is reminiscent of a turbulent flow. This pattern intimates that the book's dynamics may be quite different from the driving force behind the historical documentaries and folktales it contains, pointing perhaps to a different poiesis for narrative and a different mode of reading.

\section{Channeling the flow}

3 Movement in Operation Wandering Soul is everywhere associated with the turbulent displacement of fluids. Californian freeways "meander" like rivers. London crowds of schoolchildren en route for evacuation "seeth[e] about in the waiting chambers and spill onto the platforms" (41) at Waterloo. Living floods of rats surging "surflike in curlers and cleansing eddies" (224) swarm the streets of Hamelin. The novel makes such repeated use of the motif that the world it describes is awash with vast tumultuous migration flows. In this respect, Operation Wandering Soul may indeed be construed as a text about turbulence, about what narrative and writing do with turbulence.

4 The embedded narratives often depict turbulence as a disruptive force. Typically, they use turbulent flows as visual metaphors for troubled times, as in the description of London under the Blitz, or in the passage relating the 1527 Sack of Rome. More specifically turbulence can be defined as what inflicts destruction on structures and communication routes: the Hamelin rats threaten to bring about the ruin of the town by gnawing through its "infrastructure" (215), literally undermining it, and in the London episode, streets get so congested by the "swells of schoolchild files" that "[c]rossing Blackfriars alone require[s] minor divine intervention" (40-41). Because turbulence is Armageddon by another name-the harbinger of imminent disaster-it is imperative that it be checked; its disruptive billowing streams must be diverted and channeled to a place where they can be set at rest. The embedded narratives depict such containment operations: in London-"Where the charter'd Thames doth flow"Chriswick, a teacher at Prince Edward's School, shepherds a turbulent flock of children to their assigned destination in Canterbury where they end up sitting silent in church, while at the far end of Europe, the piper leads the rolling waves of Hamelin rats down into the Weser.

5 Because the stories are explicitly presented as textual artifacts, the reader is invited to consider the metatextual dimension beyond their factual and symbolical contents. These can be viewed as metaphorical representations of the way the narratives process turbulence. The individual figures leading travelers to their places of destination reflect the tales' linear progress, their desire for closure and meaning; the leaders are the guardians of narrative order. The turbulent agents on the other hand, be they children or rodents, seem to stand for narrative's antagonistic other; they disrupt structure and block the way, they prevent the advent of meaning. They are noisy parasites jamming the communication channel, and as such they must be silenced. The numerous images showing rowdy crowds getting into "lines" (38) are therefore transparent metaphors for narrative reining in turbulence by subjecting it to textual 
linearity. The key passage depicting the frontispiece to The Treasure Chest Illustrated Classics from which one of the inset narratives is taken provides a good illustration of the process: "A picture book narrator, perched in the sky, looks down from miles onto a map where ink-etched ocean boldly wraps blocks of continent in currents of purest palette" (173). Along with other details such as a "swirl of cloud" and "the puckered face of a blowing wind," the "currents" of color usher turbulence into this representation of a world afloat. Yet, as the description unfolds under the supervising eye of the Godlike narrator, the currents merge into an altogether different pattern: "Ink and water color snake into lines of supplicants ready to sacrifice all purchase on earth to reach their holy sites" (174). The bold, free-flowing, snaking streams of color gain structure, solidity, linearity and purpose until the watercolor picture itself finally gives way to the neat parade of print: "Tinted print starts to hover just above the frames. (...) 'Pilgrimage,' the captions begin, 'is the path of a single life made visible, replayed in the space of a few days"' (174). Text and narrative have harnessed the turbulent flow, and the caption provides an appropriate description of the clarifying process they intend to carry through to a successful conclusion.

The antagonistic relationship between turbulence and the embedded narratives thus seems to emerge as a corollary to the pedagogical function the latter assume so conspicuously throughout the novel. Indeed, all the embedded tales are intended for children, and it is no coincidence that most of the stories feature pedagogues as their main protagonists, be they regular teachers like Chriswick, or child leaders like the flute player-the Greek word paidagogos, it should be reminded, means literally "one who leads children." Ranging from cosmogonic mythology to historical account to folktale, the stories explore different modes of ordering experience through narrative; they mean to light the way for the child reader and guide him through a chaotic world.

7 And yet, given the above, it is clear that the tales are pedagogues gone astray. Their supposedly enlightening descriptions of the world are erroneous and misleading as they substitute the order of narrative for the turbulent disorder of the real. The gap between the two is so unbridgeable that Linda, the physical therapist at Carver who reads stories to her young patients, feels she must apologize to the children for the virtuality of narrative when she realizes how far her tales have strayed from reality: to a little Laotian girl who has drifted across the ocean in an open boat only to land up in the chaos of an inner-city hospital with incurable cancer, she cries out: "Oh God. Joy. I'm so sorry. I wasn't thinking. I completely forgot. Oh, child, forgive me. It's only a story" (89); the story is about how the "children of Europe" had sailed across the Atlantic to a safer and better place.

8 Linda is right to apologize, for the closure-bound narrative not only deprives the reader of the map that might help him find his way around the world, it also lures him away from this world and shuts him up in the closed virtual space of tales. This is what the recurring motif of children led away from home by their pedagogues into out-ofthis-world places intimates. Chriswick's schoolchildren disappear without a trace - "they had shaken loose of the real" (48), the narrator says laconically-in just the same way as the Hamelin children vanish through "a portal of blue" gaping wide in the mountain wall, a portal significantly associated with "the slats of a secret bookcase" (232) as if to imply that every tale-driven child will be locked up in narrative space. But there is even more to this than the painful recognition of the kind of escapism narrative might foster. Narrative is a lie. It hushes up what it will not or 
cannot speak. It glosses over the senseless proliferating turbulence that is repugnant to narrative law. It hastens to cover it up with cosmetic endings, metaphorizing it into the soothing vision of children vanishing through a portal of blue when actual endings are much darker and far beyond narrative's grasp, as all the pediatrics wards of the world are here to remind us.

The tragic virtuality of narrative, its powerless illusionism, is perhaps best exemplified in the novel by its embedded anthology of Millenarianism down the ages, showing the different ways the enterprise went wrong. Eschatology is some sort of master narrative here, the template for all tales. Its purpose is to translate the turbulent flow of history into the safe metaphor of a meaningful script whose epiphanic ending is to redeem all senselessness. Such narrative however does not put an end to turbulence; it can only lead its followers to more carnivals of madness and death, spawning endless files of martyrs and victims: the child crusaders marching under the banner of Stephen of Cloyes in 1212; the Anabaptist inhabitants of besieged Münster in 1535; all the anonymous armies of children glimpsed periodically in the book, enlisted in the latest war to end all wars; and, disseminated in the whole text, always metaphorized, like the turbulence it cannot speak nor put an end to, the haunting, almost subliminal visions of children evacuated by the million "on those night transport trains" (347). All these wandering souls come as a cruel reminder that the "end of history" (141)-or the end of the story for that matter-is a narrative sleight of hand, the codename of the tale's powerlessness. They enjoin us to reform our narrative and reading habits. For the antiturbulence narrative and its attendant evils are the offspring of our deepest reading instincts.

\section{Turbulent text versus linear narrative}

10 The novel's embedded stories are often accompanied by a staging of their own reading which displays the reader's ingrained habits. They picture him as a traveler making his way through the text, looking for clarification, and hurrying toward the foreannounced end of the narrative. In the prologue to the illustrated volume on Millenarianism, the narrative voice addresses the implied reader of the book: "Wait, walk along enough, and you will arrive. The hinted-at place is just around the next hillside. It will appear in your lifetime, in another half page or two" (175). The reader is a pilgrim and reading is the flipside of eschatology. "To scan these lavish psalter sheets," the voice resumes, "is almost to see through the panels from the other side, to surprise the reading youth under the sheets at night again. Arrows leading from square to square mark a flagstone picture path down which the strip's original owner raced by flashlight to reach story's end" (176). It is this reading habit Operation Wandering Soul sets about disturbing. The book is an operation carried out to make the reader wander in an open-ended text whose main educational value is to teach him that if the narrative ever aspires to cure itself of virtuality in the hope to say something of the world and contain a small piece of its unspeakable turmoil, then it has to be just as messy and turbulent as the world it tries to depict. The book Richard Kraft reads as an adolescent in a Buddhist monastery in Thailand provides a perfect miniature of the novel's project. The book is called An Awareness of Air, and its poetics goes against the grain of all the above described narratives, reversing their effort to clear the noisy channel: "This book," Kraft remembers, "started out as clear as the moon in a still 
water barrel, yet grew infinitely infolded with each rereading. Every line undid and removed the previous opaline paradox" (261).

But how is the text going to stir the water in the bucket? What disturbance, what turbulence is it to admit? I have already hinted at the disruption of the text's narrative line and at the sense of circularity the whole novel generates. This however is but the most visible tip of the iceberg, the surface trace, the signature-almost the metaphorof turbulent processes at work on a deeper level in Powers' writing. In order to identify these processes and understand how they operate, one must pause a minute and consider what turbulence is. Clues as to the nature of turbulence may be found in the opening pages of the book which, as one remembers, describe a traffic jam. Traffic jams have often been analyzed by scientists (for instance by physicist Illya Prigogine) as prime examples of dynamic nonlinear systems also known as chaotic or turbulent systems. Caught in a traffic jam, Kraft reflects on its erratic flow and how it enfolds a strange kind of hidden order: "He is under the impression, and would like to go empirical on this, that the city's top-polling radio tune at any given minute has a marked influence on traffic's turbulence" (7). The music playing from the car radios makes the flow evolve into changing patterns. A signal issuing from the system feeds back into the system, causing it to reorganize itself. This informational feedback loop is one of the characteristic features of turbulent systems: they evolve into constantly changing patterns generated by recursion; they are self-organizing systems. Order (pattern, information) can emerge spontaneously from disorder. This is confirmed in another passage from the traffic jam episode, which adds one more touch to the description of turbulence:

Several hoods in front of him, sleek little fuel-injected Alpha particle manned by sandalwood-haired guy hugging cellular phone swaps places with convertible Stuttgart-apparatus piloted by blond bombshell lip-syncing to the same song Kraft has tuned in on the radio. Eight seconds later, for no reason in creation, the two swap back. The exchange is duplicated all across the event horizon, a synchronized, pointless, mass red shift. (5)

12 This paragraph suggests how the system's minutest fluctuations are amplified into large-scale changes (this is the popularized "butterfly effect"): the unpredictable movements of the cars-they are swapping places "for no reason in creation"propagate in identifiable patterns across the whole space-time continuum, testifying to the existence of some underlying architecture. The ripple effect hinted at at the end of the passage by the "red shift"-which refers to an increase in wavelength of electromagnetic radiation-implies the fractal-like structure of the system, its recursive symmetries. The repetition of the same general configurations across multiple levels and multiple length scales within the system acts as a complex and unpredictable coupling mechanism between the levels that rapidly transmits changes (like swapping places) from the local to the global.

This most sketchy description of chaotic systems suffices to shed some light on how Powers' novel can turn itself into a turbulent text. As we read our way through the book, looking for coherence, we see patterns emerge. We see them all the more clearly because the composition of the text is based on fractal structures: for instance, the embedded narratives form a book collection in the main narrative, which, as it turns out, happens to be a book itself (it is Richard Powers' manuscript of Operation Wandering Soul). Besides, the novel contains numberless scale models of itself. James Hurt has 
analyzed how a bank of television monitors "trawl[ing] at random for a half-dozen picture signals and flaunt[ing] these in assembled, inscrutable patterns" (163) is one of the many miniatures of the whole textual system and of its dynamics. Furthermore, on different levels of the text, the same motifs keep recurring; Kraft's personal story mirrors that of the displaced children in both the main and inset narratives. The main narrative itself reads like a rewriting of the already revised version of "The Pied Piper of Hamelin" that the book contains. Characters from the main story make cameo appearances in the embedded stories and vice versa, looking like reincarnations of themselves. Many protagonists, like Joy, the little Laotian refugee, are nested structures of metaphors within metaphors: her cancer-ravaged body, "the terminallyill Angel City" (344), and the proliferating body of the text are woven together into a dense symbolic network. Looking into Joy's body, like Kraft operating on it, the reader like the surgeon sees the whole text and the whole world within the text: "What in creation is this thing? Smooth, slick, rippled, striated, zoomable to full complexity at every magnification? His textbook snip sneaks through the slippery veneer, revealing whole structures folded within structure" (267).

Now, this fractal composition induces a dynamic process of recursion. In An Awareness of Air, this process is set in motion by the constant rereading of the text. In Operation Wandering Soul, recursive symmetries alone turn the text into an endless rereading of itself, causing it to grow "infinitely infolded." In fact, the book is one massive, intricate layering of informational feedback loops. Each one of these loops reorganizes the system. It undoes and reweaves it by feeding differences or "noise" into it, for the text never repeats itself word for word. With each reprise, the motifs and patterns reappear in altered and garbled forms. Hence the constant sense of recognition-the "weirdly familiar" (163), the "somehow familiar" (165)-that the reader shares with so many characters in the narrative. In the Canterbury church where he has chanced upon a group of rehearsing choirboys, Chriswick goes through an experience which clearly reflects the reader's own:

[The hymn] started out in Latin, but soon became very Anglican. The text turned into a dog's breakfast-bits and pieces from the Book of Common Prayer. It had been too long to be sure, but Chriswick seemed to make out familiar lines, like forgotten but still familiar faces from old school photographs. (45 emphasis mine)

And because the text has a fractal structure, any transformation fed into one of its components by the recursion of familiar but not quite identical motifs has incalculable consequences on the perception of the whole, prompting the reader to constantly reorganize the narrative he has been assembling, and sometimes radically so. For deep in the fractal structure, Powers has planted "double agent[s]" (191) acting as operators of ambiguity. They are liable to invert a pattern and reverse its meaning at a moment's notice. The double agent can be a simple word, like "rat" which refers now to victims, now to victimizers, now to the disruptive forces of confusion, now to some orderly anarchy, some dissipative structure ("the living flood admits to no shoving, no panic, no collapse of societal mores at all; more of a dense, euphoric dance, cobbles pounded in time to the soaring tune" [224]). Or the double agent can be a character, like Nicolino. The boy weaves several key patterns together: he is both Peter Pan and the Piper, the troublemaker and the organizer, the emancipator and the tyrant, and because he suffers from progeria, he is child and adult rolled into one. In short, he 
destabilizes the categories which provide the novel with its infrastructure. He turns the whole text upside down-and several times over.

A prominent example of how the dynamics of turbulence informs the workings of the text may be found in the Canterbury church episode. The sudden and unexpected appearance of American choirboys in the church at the end of chapter 3 may first be construed by the reader-as it is by the narrator-as a lull in the midst of the chaotic times the protagonists and the whole world are going through. More specifically, the encounter is described as a moment of order, peace, and harmony that is free of all disturbing interference: "Every lad in the dozen possessed uncanny musical maturity; they'd been singing for twenty minutes, a cappella, without straying from pitch" (46 emphasis mine). This interpretation, however, is soon to be challenged by later episodes in the narrative that retrospectively, like some feedback loop, stir the pool of tranquility into a noisy channel. With the benefit of hindsight, the reader, recalling the Canterbury church peaceful episode, will be cued to associate some of its features with disquieting elements met further on in the novel. For instance, the links between the choristers and the Pied Piper are many: they are strangers; their music has a mesmerizing effect on the audience; the London children vanish in their wake as if spirited away, "shaken loose of the real" (48). The choirboys are also linked by the type of music they interpret with the proponents of eschatological narratives. The Canterbury church episode may thus turn out to be one of the early appearances in the book of "the old road to simplification" and our first glimpse of its harmful consequences. Furthermore, other details like the "High Church bauble" in one of the singers' palm-a trumpeting-toting angel (...) with an astonishing disfigured face" (47) -will accrete more and more conflicting semantic values and connections as the talisman changes hands, following its unpredictable nonlinear course through the narrative, surfacing in unexpected places and contexts, its astonishing disfigurement hinting programmatically at its capacity to embody itself in many-faced avatars. These transformations, which prompt the reader to revise the narrative he had first put together, suggest how the text is designed to make new patterns emerge through feedback loops and interferences. Undoing and reweaving itself constantly, the novel ushers the reader into more complexities and more levels of interpretation that force narrative out of its simplifying and turbulence-channeling linearity.

I cannot hope, of course, to trace the innumerable transformations and reincarnations the text goes through overtime, if only because these are unpredictable, both for the reader, who will gasp at all the hidden correspondences and the secret symmetries he had missed out on previous readings, and for the author himself as the transformations are dependent on how the reader processes the noise that feeds back into the systemauthor, reader, and text (or in Powersian parlance, "teller, tellee, and told" [244]) forming a chaotic system all their own. If one were to map, however, the fluid transformation of this text orbiting around the same recurring patterns while never following quite the same path, I suspect one would get something like a Lorenz attractor, the strange diagram showing the evolution of a turbulent system. An attractor is any point of the system's cycle that seems to attract the system to it, like the midpoint of a pendulum's path for instance, or like the recurring motifs in Powers' text. In the case of non-linear systems, no two orbits ever exactly coincide, creating this infinite layering of loops, and each loop, although confined within the region of the attractor, follows an unpredictable course. There is thus no telling when the system is 
going to swing to the other side of the axis of symmetry. Likewise there is no telling what infinite path leading nowhere but to more variations on itself the text is going to take the reader, nor when it will pull the rug out from underneath his feet. Operation Wandering Soul is a turbulent text indeed, and strangely attractive too, what Roland Barthes might have called un texte de jouissance, one that promises no delusive epiphany but only more confusion-one, however, that truly frees the reader from the virtual order of tales and leads the way to a perception of narrative as rich simulation of the real.

\section{BIBLIOGRAPHIE}

BURN, Stephen J. and DEMPSEY, Peter (eds.), Intersections: Essays on Richard Powers (Champaign and London: Dalkey Archive Press, 2008).

HAYLES, Katherine, Chaos Bound, Orderly Disorder in Contemporary Literature and Science (Ithaca and London: Cornell University Press, 1990).

- (ed.), Chaos and Order (Chicago and London: University of Chicago Press, 1991).

HOFSTADTER, Douglas, Gödel, Escher, Bach: an Eternal Golden Braid (New York: Basic Books, 1979),

Chapter XX, “Strange Loops, Or Tangled Hierarchies", 684-719.

HURT, James, "Narrative Powers: Richard Powers as Storyteller", Review of Contemporary Fiction 18:3 (Fall 1998), 24-41.

KERMODE, Frank, The Sense of an Ending: Studies in the Theories of Fiction (Oxford: Oxford University Press, 2000).

LECLAIR, Tom, "The Prodigious Fiction of Richard Powers, William Vollmann, and David Foster Wallace", Critique: studies in contemporary fiction 38:1 (Fall 1996), 12-37.

PAULSON, William, "Literature, Complexity, Interdisciplinarity" in Chaos and Order, K. Halyes (ed.) (Chicago and London: University of Chicago Press, 1991), 37-53.

PORUSH, David, “Fiction as Dissipative Structures: Prigogine's Theory and Postmodernism's Roadshow" in Chaos and Order, K. Halyes (ed.) (Chicago and London: University of Chicago Press, 1991), 54-84.

STOICHEFF, Peter, "The Chaos of Metafiction" in Chaos and Order, K. Halyes (ed.) (Chicago and London: University of Chicago Press, 1991), 85-99.

LINDNER, April, “Narrative as Necessary Evil in Richard Powers's Operation Wandering Soul”, Critique: studies in contemporary fiction 38:1 (Fall 1996), 68-79.

NEILSON, Jim, “An Interview with Richard Powers”, The Review of Contemporary Fiction 18:3 (Fall 1998), 13-23.

MANDELBROT, Benoît, Les Objets fractals (Paris, Flammarion, 1995). 
PELLEGRIN, Jean-Yves, “Only the Conversation Matters: an Interview with Richard Powers", European Journal of American Studies, EJAS 2007-1, [Online], article 2, put online Apr. 27, 2007. http://ejas.revues.org/document1145.html.

\section{RÉSUMÉS}

Dans le roman de Richard Powers Operation Wandering Soul, la linéarité conventionnelle du récit cède le pas à une forme de discontinuité et de circularité qui évoque le mouvement imprévisible d'une turbulence. On propose de montrer ici que cette turbulence met en œuvre une nouvelle manière d'écrire et de lire les récits. Dans le roman, la turbulence apparaît toujours sous l'aspect d'une force désorganisatrice qu'il faut maîtriser, un bruit qui doit être supprimé. Cet impératif, témoin des aspirations du récit au sens et à la clôture, peut se concevoir comme l'indice de la manière dont l'ordre narratif s'efforce de soumettre toute turbulence en dissimulant son chaos sous une linéarité de façade et des dénouements postiches. Cette activité transforme le récit (et le type de lecture qu'elle induit) en une sorte d'eschatologie dont Operation Wandering Soul dénonce le mensonge et la fuite en avant. Pour en combattre les effets néfastes, le roman s'emploie à perturber l'ordre narratif et à bousculer nos habitudes de lecture; il se fait texte turbulent en conformant sa structure la plus intime à celle des systèmes non linéaires.

In Richard Powers' Operation Wandering Soul, the conventional linearity of narrative gives way to a type of discontinuity and circularity that is reminiscent of the unpredictable movement of turbulent flows. This paper suggests that such turbulence enacts a new way of writing and reading narrative. Turbulence is always described in the novel as a disruptive force that must be checked or a noise that must be silenced. This imperative, which testifies to narrative's desire for closure and meaning, may be construed as an index of the way narrative order attempts to subdue all turbulence by covering up its proliferating chaos with perfunctory linearity and cosmetic endings. Such activity turns narrative-and the type of reading it encourages-into some kind of eschatology which Operation Wandering Soul denounces as a lie and a form of escapism. In order to counter their harmful effects, the novel thus sets about disturbing narrative order and our reading habits by turning itself into a turbulent text, modeling its innermost structures on that of nonlinear systems.

\section{INDEX}

Mots-clés : Récit, système, turbulence, fractales, Edward Lorenz

Keywords : Narrative, system, turbulence, fractals, Edward Lorenz

\section{AUTEUR}

\section{JEAN-YVES PELLEGRIN}

Université Paris-Sorbonne (Paris IV) 